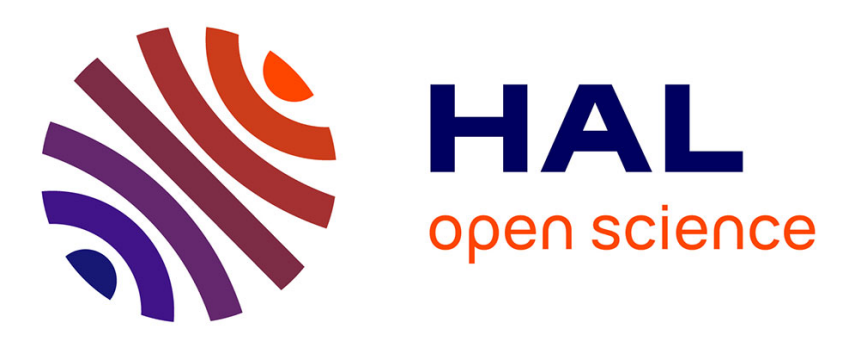

\title{
Multicomponent reactions in PEG-400: ruthenium-catalyzed synthesis of substituted pyrroles
}

Srivari Chandrasekhar, Vidyavathi Patro, Lahu N., Rambabu Chegondi, René Grée

\section{- To cite this version:}

Srivari Chandrasekhar, Vidyavathi Patro, Lahu N., Rambabu Chegondi, René Grée. Multicomponent reactions in PEG-400: ruthenium-catalyzed synthesis of substituted pyrroles. Tetrahedron Letters, 2014, 55 (43), pp.5932 - 5935. 10.1016/j.tetlet.2014.08.105 . hal-01072726

\section{HAL Id: hal-01072726 \\ https://hal.science/hal-01072726}

Submitted on 8 Oct 2014

HAL is a multi-disciplinary open access archive for the deposit and dissemination of scientific research documents, whether they are published or not. The documents may come from teaching and research institutions in France or abroad, or from public or private research centers.
L'archive ouverte pluridisciplinaire HAL, est destinée au dépôt et à la diffusion de documents scientifiques de niveau recherche, publiés ou non, émanant des établissements d'enseignement et de recherche français ou étrangers, des laboratoires publics ou privés. 
Multicomponent reactions in PEG-400:

Leave this area blank for abstract info. ruthenium-catalyzed synthesis of substituted pyrroles

Srivari Chandrasekhar ${ }^{* a}$, Vidyavathi Patro ${ }^{\mathrm{a}}$, Lahu N. Chavan ${ }^{\mathrm{a}}$, Rambabu Chegondi $^{\mathrm{a}}$, René Grée ${ }^{\mathrm{b}}$

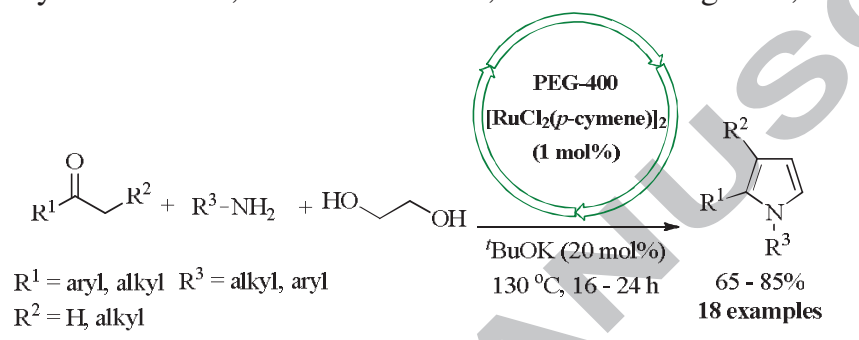




\section{Multicomponent reactions in PEG-400: Ruthenium-catalyzed synthesis of substituted pyrroles

\author{
Srivari Chandrasekhar ${ }^{\mathrm{a}, *}$, Vidyavathi Patro ${ }^{\mathrm{a}}$, Lahu N. Chavan ${ }^{\mathrm{a}}$, Rambabu Chegondi ${ }^{\mathrm{a}}$, René Grée ${ }^{\mathrm{b}}$
} \\ ${ }^{a}$ Division of Natural Products Chemistry, CSIR-Indian Institute of Chemical Technology, Hyderabad-500 007, India \\ ${ }^{b}$ Université de Rennes 1, Institut des Sciences Chimiques de Rennes, CNRS UMR 6226, Avenue du Général Leclerc, 35042 Rennes Cedex, France}

An efficient and eco-friendly method for the synthesis of substituted pyrroles has been developed via ruthenium-catalyzed multicomponent reaction of ketone, amine and ethylene glycol in PEG-400 as solvent medium without using any external ligand. The catalytic system and solvent can be recycled with the same, as well as different, ketones with minimum loss of Ru-catalyst activity.

Multicomponent reactions (MCRs), ${ }^{1}$ eco-friendly solvents ${ }^{2}$ and catalysis ${ }^{3}$ have been central themes in green chemistry. Incorporation of these principles into the formation of new C-C and $\mathrm{C}-\mathrm{X}$ bonds paves the way towards the preparation of new chemicals and products in agrochemicals, pharmaceuticals and materials in an economical fashion. In particular, the use of recyclable and reusable solvents are gaining prominence for organic reactions. ${ }^{4}$ In this direction, we have demonstrated in our early studies that PEG-400 is a preferred solvent medium wherein the expensive metals and their complex could be recovered and reused effectively without loss of activity. ${ }^{5}$

Since the first synthesis of "pyrrole" ring by Knorr way back in 1884 , the preparation of pyrroles has come a long way over the past century. ${ }^{6}$ Several approaches viz, [3+2] cycloadditions, ${ }^{7}$ $[4+1]$ approach, $^{8}[2+2+1]$ approach $^{9}$ and intramolecular versions ${ }^{10}$ have been developed for the synthesis of pyrroles. These approaches are compiled in excellent reviews by Ferreira ${ }^{11}$ and Menendez. ${ }^{12}$ Recently, a novel three-component method for pyrrole synthesis has been reported by the Beller's group using ruthenium catalysis, assisted by Xantphos as ligand, in a [2+2+1] strategy for pyrrole formation. ${ }^{13}$ This work combined with our experience in using PEG-400 as a solvent medium, ${ }^{5}$ prompted us to look at the recyclability of expensive Ru-catalyst in such a pyrrole synthesis.

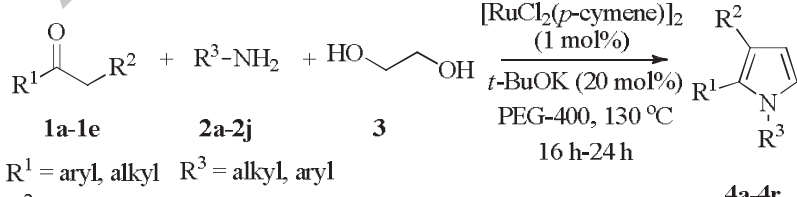

$$
\begin{aligned}
& \mathrm{R}^{2}=\mathrm{H} \text {, alkyl }
\end{aligned}
$$

Scheme 1. Synthesis of substituted pyrroles in PEG-400

*Corresponding author. Tel.: +91 40 27193210; fax: +91 4027160512 E-mail address: srivaric@iict.res.in (S. Chandrasekhar).
The results pertaining to Ru-catalyzed three-component pyrrole synthesis with a recyclable medium ( $\mathrm{Ru}$ and PEG-400) are reported herein (Scheme 1). Furthermore, a significant advantage of the described method is that the expensive ligand (xantphos) is avoided since the PEG-400 acts as external ligand. ${ }^{14}$

In the first instance, cyclopentanone 1a, cyclohexylamine 2a and ethylene glycol 3 were chosen as partners in the $[2+2+1]$ condensation process (Table 1, entry 1 ). The reaction in PEG-400 in the presence of $1 \mathrm{~mol} \%\left[\mathrm{RuCl}_{2}(p \text {-cymene })\right]_{2}$ and $20 \mathrm{~mol} \% t$ BuOK catalytic system was successful and the 1,2,3-trisubstituted pyrrole 4a was isolated in $75 \%$ yield, after a routine work-up process. ${ }^{5 \mathrm{k},}{ }^{15}$ With this observation on hand, the reaction generality was studied by performing experiments with various substrates. Keeping cyclopentanone 1a and ethylene glycol $\mathbf{3}$ as the common partners, 4-methoxybenzylamine $\mathbf{2 b}$ (Table 1, entry 2) and $n$-butyl amine 2c (Table 1, entry 3 ) as variable amine counterparts, the pyrroles $\mathbf{4 b}, \mathbf{4 c}$ were obtained in decent yields. To understand the patterns for aryl ketones, phenylethylketone $\mathbf{1 b}$ and ethylene glycol $\mathbf{3}$ as common partners were treated with benzyl amine 2d, 4-methoxy aniline 2e, $(R)-(+)-1-(1-$ naphthyl)ethyl amine 2f, cyclohexylamine 2a, $n$-butyl amine $\mathbf{2 c}$ to give the trisubstituted pyrroles $\mathbf{4 d - h}$ respectively in satisfactory yields (Table 1, entries 4-8). In addition, other ketones such as acetophenone 1c with benzyl amine $\mathbf{2 d}$ and cyclopropylamine $\mathbf{2 g}$ gave disubstituted pyrroles $\mathbf{4 i}$ and $\mathbf{4} \mathbf{j}$ respectively in acceptable yields (Table 1, entries 9 and 10). The cyclohexanone 1d provided bicyclic fused pyrroles $\mathbf{4 k} \mathbf{k}-\mathbf{n}$ with $(S)$-phenylethylamine $\mathbf{2 h}$, butylamine $\mathbf{2 c}$, benzylamine $\mathbf{2 d}$, aniline $\mathbf{2 i}$ consistently well (Table 1, entries 11-14). Another ketone, $\alpha$-tetralone 1e was attempted with butylamine $\mathbf{2 c}$, 4-chlorobenzylamine $\mathbf{2 j}$, benzylamine $\mathbf{2 d}$, cyclopropylamine $\mathbf{2 g}$ providing angular tricyclic pyrroles 4o-r respectively in the $75-85 \%$ yield range (Table 1 , entries 15-18). For direct comparision of present method with Beller's protocol, the experiments were performed with 2phenylethylamine (2k) as one of the partners (Table 1, entries 19 and 20). The observations reveal that the yields obtained with the 
new system are marginally lower, however offers an additional advantage that the external ligand is not required.

Table 1: Ruthenium-catalyzed synthesis of substituted pyrroles

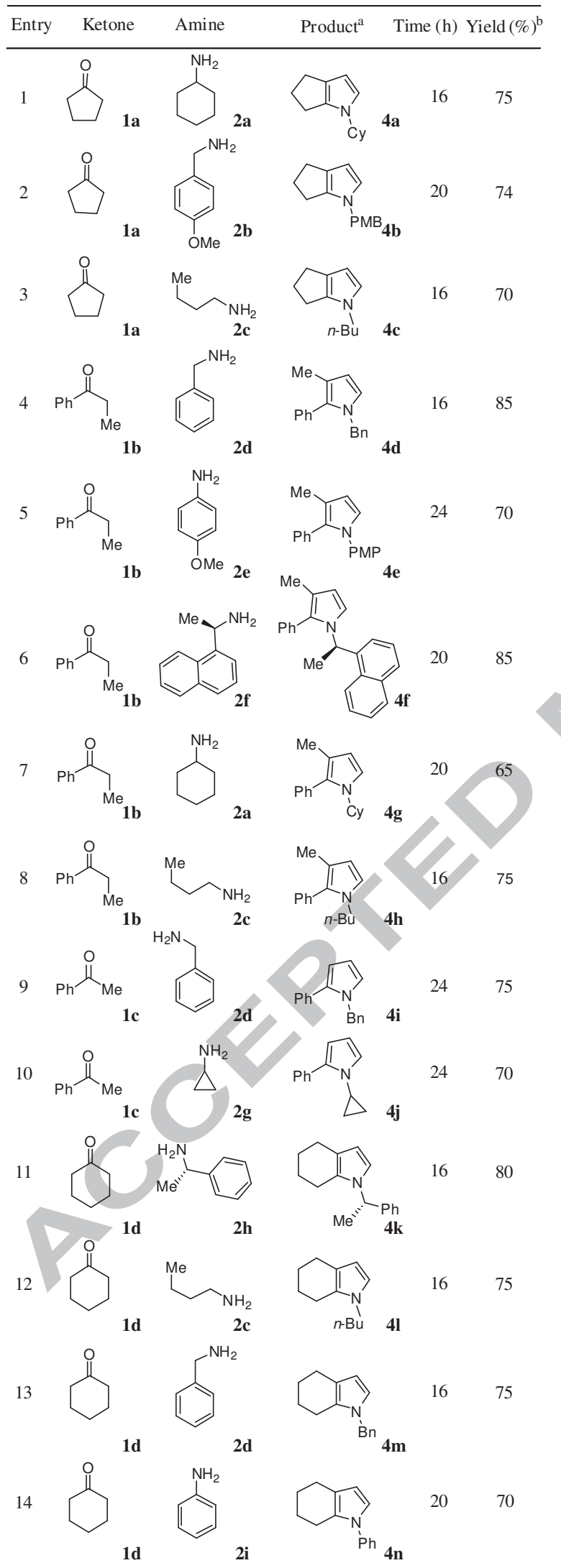

15<smiles>O=C1CCCc2ccccc21</smiles><smiles>C[Mg]CCCN</smiles><smiles>CC(C)n1ccc2c1-c1ccccc1CC2</smiles>

40

16<smiles>NCc1ccc(Cl)cc1</smiles>

$\mathrm{Cl}$<smiles>Clc1ccc(Cn2ccc3c2-c2ccccc2CC3)cc1</smiles>

17<smiles>NCc1ccccc1</smiles>

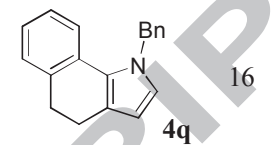

85

18<smiles>O=C1CCCCC1C1CCCC1</smiles><smiles>NC1CC1</smiles>
$2 \mathrm{~g}$<smiles></smiles>
75<smiles>C[C@@H](Cn1cccc1-c1ccccc1)C(C)(C)C</smiles>

20<smiles>Cc1ccccc1CCN</smiles>

${ }^{a}$ All products were characterized by ${ }^{1} \mathrm{H},{ }^{13} \mathrm{C}$ NMR and Mass spectroscopy.

Isolated yield after column chromatography.

${ }^{c}$ Reported yield (Ref. 13a)

Further, the efficacy of the developed method by recycle and reuse $^{12}$ of expensive ruthenium catalyst, has been demonstrated. Towards this, entry 13 (Table 1) has been chosen as representative example. Thus, $\mathbf{1 d}$ and $\mathbf{2 d}$ were condensed with ethylene glycol 3 in the presence of $t$-BuOK for over five times using the same PEG-400 and ruthenium catalyst with good yields without significant loss of catalytic activity (Table 2). Also, the cross over experiments performed with three different ketones (Table 3) demonstrated that the products could be completely extracted from PEG and no detectable contaminations were observed. However, due the aqueous work-up process, $20 \mathrm{~mol} \%$ $t$-BuOK has to be added after each run. Here also, an addition of $0.2 \mathrm{~mol} \%\left[\mathrm{RuCl}_{2}(p \text {-cymene })\right]_{2}$ allowed us to improve the yields in next runs.

Table 2: Recyclability of catalyst in PEG-400<smiles>O=C1CCCCC1</smiles>

1d
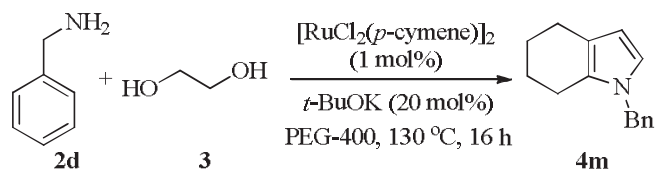

\begin{tabular}{|c|ccccc|}
\hline Run & 1st & 2nd & 3rd & 4th & 5th \\
\cline { 2 - 6 } Yield (\%) & 75 & 72 & 70 & $65(70)^{*}$ & $63(70)^{*}$ \\
\hline
\end{tabular}

asolated yield af ter column chromatography

* An additional $0.2 \mathrm{~mol} \%$ 'Ru' catalyst was added to the reaction 
Table 3: Recyclability of catalyst and solvent in crossover experiments

\begin{tabular}{|c|ccc|}
\hline Run & Ketone & Product & Yield (\%) $^{\mathrm{a}}$ \\
\cline { 1 - 4 } 1st & $\mathbf{1 d}$ & $\mathbf{4 m}$ & 75 \\
2nd & $\mathbf{1 e}$ & $\mathbf{4 o}$ & 70 \\
3rd & 1b & $\mathbf{4 h}$ & $65(75)^{*}$ \\
\hline
\end{tabular}

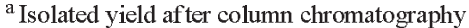

*An additional $0.2 \mathrm{~mol} \%$ 'Ru' catalyst was added to the reaction

Based on these findings, it may be inferred that the $[2+2+1]$ condensation for pyrrole synthesis proceeds smoothly in PEG, even in the absence of any added ligand, via imine formation between ketone and amine, followed by dehydrogenation of ethylene glycol to an in situ generated dialdehyde for further condensation to form pyrrole. ${ }^{11}$

Disappointingly, the substituted vicinal diols viz, 2,3butanediol, 1,2-diphenylethane-1,2-diol, cyclohexane-1,2-diol and 2-phenylethane-1,2-diol did not participate in the pyrrole synthesis. However, $\alpha$-hydroxyacetone $\mathbf{5}$ when subjected to the coupling protocol with ketones $\mathbf{1 d}$ or $\mathbf{1 e}$ and $n$-butylamine (Scheme 2) provided the pyrroles $\mathbf{4 s}$ and $\mathbf{4 t}$ in moderate yields.

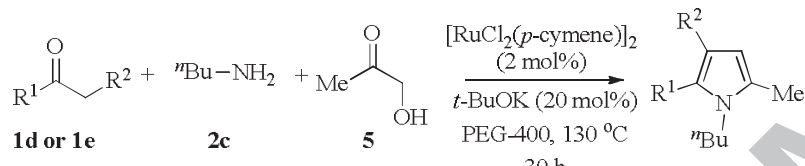<smiles>Cc1cc2c(n1C)CCCC2</smiles>

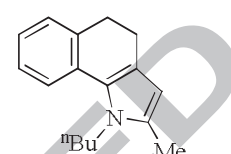

4s (42\%)

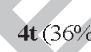

Scheme 2. Synthesis of $\alpha$-methyl substituted pyrroles in PEG-400.

These results endorse that the developed methodology follows the major principles of green chemistry wherein catalyst and solvent are recyclable. This MCR is well tolerated in PEG-400, with $\mathrm{H}_{2}$ and $\mathrm{H}_{2} \mathrm{O}$ as byproducts, and additionally the molecules obtained, especially the tricyclic pyrroles, are potentially useful in bioorganic and medicinal chemistry.

In conclusion, we have successfully synthesized substituted pyrroles using readily accessible ketones, amines and ethylene glycol using $\left[\mathrm{Ru}(p \text {-cymene }) \mathrm{Cl}_{2}\right]_{2}$ as catalyst and potassium tertbutoxide as base in PEG-400 without using any extra ligand. In the process, the catalyst along with PEG solvent was recycled up to five times with the same ketone, as well as with different ketones.

\section{Acknowledgments}

This research has been performed as part of the Indo-French "Joint Laboratory for Sustainable Chemistry at Interfaces". We thank CNRS, CSIR, University of Rennes 1 and CEFIPRA/IFCPAR for support of this research. V.P. \& L.N.C thank to CSIR, New Delhi, for research fellowship and R.C. thanks CSIR-SRA for financial assistance. SC thanks CSIR XII plan project ORIGIN (CSC-0108) for funding.

\section{References and notes}

1. (a) For a monograph on Multicomponent Reactions; Zhu, J., Bienaymé, H., Eds.; Wiley-VCH, 2005; (b) Dömling, A. Chem. Rev. 2006, 106, 1789; (c) Toure, B. B.; Hall, D. G. Chem. Rev. 2009, 109, 4439-4486; (d) Schreiber, S. L. Science 2000, 287, 1964-1969; (e) Carballares, S.; Espinosa, J. F. Org. Lett. 2005, 7, 2329-2331; (f) Dömling, A.; Wang, W.; Wang, K. Chem. Rev. 2012, 112, 3083-3135; (g) Shiri, M. Chem. Rev. 2012, 112, 3508-3549; (h) Orru, R. V. A.; de Greef, M. Synthesis 2003 1471-1499; (i) Tejedor, D.; Gonza' lez-Cruz, D.; Santos-Expo' sito, A.; Marrero-Tellado, J. J.; de Armas, P.; Gare1'a-Tellado, F. Chem.-Eur. J. 2005, 11, 3502-3510; (j) Guillena, G.; Ramón, D. J.; Yus, M. Tetrahedron: Asymmetry 2007, 18, 693-700 and references cited therein.

2. Hashemi, M. M.; Khalili, B.; Jajarmi, P.; Eftekhari-Sis, B. J. Org. Chem. 2008, 73, 2090-2095.

3. (a) Crabtree, R. H.; Dobereiner, G. E. Chem. Rev. 2010, 110, 681; (b) Crabtree, R. H. Organometallics 2011, 30, 17-19.

4. (a) Gu, Y. Green. Chem. 2012, 14, 2091-2128; (b) Chin, J.; Spear, S. K.; Huddleston, J. G.; Rogers, R. D. Green. Chem. 2005, 7, 64-82.

5. (a) Chandrasekhar, S.; Kavitha, N; Sukumar, G.; Kumar, V. P.; Mainkar, P. S. Tetrahedron Lett. 2013, 54, 4198-4201; (b) Chandrasekhar, S.; Patro, V.; Reddy, G. P. K.; Grée, R. Tetrahedron Lett. 2012, 53, 62236225; (c) Chandrasekhar, S.; Reddy, N. K.; Kumar, V. P. Tetrahedron Lett. 2010, 51, 3623-3625; (d) Chandrasekhar, S.; Prakash, S. J.; Rao, C. L. J. Org. Chem. 2006, 71, 2196-2199; (e) Chandrasekhar, S; Sultana, S. S.; Yaragorla, S. R.; Reddy, N. R. Synthesis 2006, 5, 839-842; (f) Chandrasekhar, S; Saritha, B.; Jagadeshwar, V.; Narsihmulu, Ch.; Vijay, D.; Sarma, G. D.; Jagadeesh, B. Tetrahedron Lett. 2006, 47, 2981-2984; (g) Chandrasekhar, S; Reddy, N. R.; Sultana, S. S.; Narsihmulu, Ch.; Reddy, K. V. Tetrahedron 2006, 62, 338-345; (h) Chandrasekhar, S; Narsihmulu, Ch.; Reddy, N. R.; Sultana, S. S. Tetrahedron Lett. 2004, 45 4581-4582; (i) Chandrasekhar, S; Narsihmulu, Ch.; Reddy, N. R.; Sultana, S. S. Chem. Commun. 2004, 2450-2451; (j) Chandrasekhar, S; Narsihmulu, Ch.; Saritha, B.; Sultana, S. S. Tetrahedron Lett. 2004, 45, 5865-5867; (k) Chandrasekhar, S; Narsihmulu, Ch.; Chandrasekhar, G.; Shyamsundar, T. Tetrahedron Lett. 2004, 45, 2421-2423; (1) Chandrasekhar, S; Chandrasekhar, G.; Narsihmulu, Ch. Synlett 2004, 3 , 522-524; (m) Chandrasekhar, S; Narsihmulu, Ch.; Sultana, S. S.; Reddy, N. R. Chem. Commun. 2003, 1716-1717; (n) Chandrasekhar, S; Narsihmulu, Ch.; Sultana, S. S.; Reddy, N. R. Org. Lett. 2002, 4, 43994401; (o) Chandrasekhar, S; Sultana, S. S.; Yadav, J. S.; Grée, R.; Guillemin, J. C. Tetrahedron Lett. 2002, 43, 8335-8337.

6. (a) Knorr, L. Chem. Ber. 1884, 17, 1635-1642. (b) Alberola, A.; Ortega, A. G.; Sadaba, M. L.; Sanudo, C. Tetrahedron 1999, 55, 6555-6566; (c) Elghamry, I. Synth. Commun. 2002, 32, 897-902; (d) Manley, J. M.; Kalman,M. J.; Conway, B. G.; Ball, C. C.; Havens, J. L.; Vaidyanathan, R. J. Org. Chem. 2003, 68, 6447-6450; (e) Shiner, C.M.; Lash, T. D. Tetrahedron 2005, 61, 11628-11640.

7. (a) Akhiyama, T.; Fuchibe, K.; Ono, D. Chem. Commun. 2006, 22712273; (b) Zhang, J. P.; Ren, C. Q.; Di, C. H.; Zhao, Y. L. Tetrahedron Lett. 2013, 54, 1478-1481; (c) Narasaka, K.; Chiba, S.; Wang, Y.; Toh, K. K.; Org. Lett. 2008, 10, 5019-5022; (d) Narasaka, K.; Chiba, S.; Wang, Y.; Lapointe, G. Org. Lett. 2008, 10, 313-316; (e) Guan, Z. H.; Zhao, M. N.; Ren, Z. H.; Wang, Y. Y. Chem. -Eur. J. 2014, 20, 1839-1842; (f) Liu, S. T.; Murugan, K. Tetrahedron Lett. 2013, 54, 2608-2611.

8. (a) Arndtsen, B. A.; Lu, Y. Org. Lett. 2009, 11, 1369-1372; (b) Rao, H. S. P.; Jothilingam, S.; Scheeren, H. W. Tetrahedron 2004, 60, 1625-1630.

9. (a) Jana, U.; Maiti, S.; Biswas, S. J. Org. Chem. 2010, 75, 1674-1683; (b) Abbasinejad, M. A.; Charkhati, K.; Ardakani, H. A. Synlett 2009, 7 , 1115-1117; (c) Trivedi, D. R.; Bhat, S. I. Tetrahedron Lett. 2013, 54 5577-5582; (d) Arndtsen, B. A.; Daniel, J. S. C.; Martin, N. Org. Lett. 2007, 9, 449-452; (e) Kowsari, E.; Yavari, I. Synlett 2008, 6, 897-899; (f) Alizadeh, A.; Babaki, M.; Zohreh, N. Tetrahedron 2009, 65, 1704-1707; (g) Wu, J.; Zhang, L.; Wang, X.; Li, S. Tetrahedron 2013, 69, 38053809; (h) Nagarapu, L.; Mallepalli, R.; Yeramanchi, L.; Bantu, R. Tetrahedron Lett. 2011, 53, 3401-3404.

10. (a) Trost, B. M.; Lumb, J. P.; Azzarelli, J. M. J. Am. Chem. Soc. 2011 133, 740-743; (b) Rueping, M.; Parra, A. Org. Lett. 2010, 12, 5281-5283; (c) Park, C. M.; Jiang, Y.; Chan, W. C. J. Am. Chem. Soc. 2012, 134 
4104-4107; (d) Buchwald, S. L.; Martin, R.; Rivero, M. R. Angew. Chem. Int. Ed. 2006, 45, 7079-7082; (e) Huang, X.; Shen, R.; Zhang, T. J. Org. Chem. 2007, 72, 1534-1537; (f) Maruoka, K.; Ooi, T.; Ohmatsu, K.; Ishii, H.; Saito, A. Tetrahedron Lett. 2004, 45, 9315-9317; (g) Akai, S.; Egi, M.; Azechi, K. Org. Lett. 2009, 11, 5002-5005.

11. Ferreira, V. F.; Maria, C. B. V. D.; Anna, C.C.; Pereira, L. O. R.; Maria, L. G. F. Org. Prep. Proce. Int. 2001, 33, 411-454.

12. Menendez, J. C.; Estevez, V.; Villacampa, M. Chem. Soc. Rev. 2010, 39 4402-4421.

13. (a) Beller, M.; Zhang, M.; Fang, X.; Neumann, H. J. Am. Chem. Soc. 2013, 135, 11384-11388; (b) Beller, M.; Zhang, M.; Neumann, H. Angew. Chem. Int. Ed. 2013, 52, 597-601.

14. The $\mathrm{OH}$ groups of PEG can act as ligands see: (a) Mao, J.; Ji, S. J.; Guo, J.; Fang, F. Tetrahedron 2008, 64, 3905-3911; (b) Wang, Y.; She, J.; Jiang, Z. Tetrahedron Lett. 2009, 50, 593-596; (c) Reddy, G. C.; Balasubramanyam, P.; Salvanna, M.; Das, B. Eur. J. Org. Chem. 2012, 471-474; (d) Framery, E.; Adidou, O.; Henry, C. G.; Safi, M.; Soufiaoui, M. Tetrahedron Lett. 2008, 49, 7217-7219; (e) De Souza, A. L. F.; Silva, A. C.; Antunes, O. A. C, Appl. Organometal. Chem. 2009, 23, 5-8; (f) Li, J. H.; Liu, W. J.; Xie, Y. X.; Liang, Y. Synthesis 2006, 5, 860-864; (g) Li, X.; Wu, Y.; Lu, C.; Shan, W. Tetrahedron: Asymmetry 2009, 20, 584587.

15. General experimental procedure: To a stirred solution of ketone (1.0 mmol) in PEG-400 (4 mL) was added amine $(1.5 \mathrm{mmol})$ at $25{ }^{\circ} \mathrm{C}$ in glass pressure tube. After $5 \mathrm{~min}$, diol $(2.2 \mathrm{mmol})$ was added followed by $\left[\mathrm{Ru}(p \text {-cymene }) \mathrm{Cl}_{2}\right]_{2}(0.01 \mathrm{mmol})$ and potassium tert-butoxide $(0.2 \mathrm{mmol})$ were added successively. The pressure tube was tightly capped and heated to $130{ }^{\circ} \mathrm{C}$. After completion of the reaction, it was cooled to room temperature. The solution was diluted with ether $(10 \mathrm{~mL})$, stirred for 10 min and was allowed to stand in ice-salt bath to solidify PEG-400. The ether layer was decanted, dried over anhydrous $\mathrm{Na}_{2} \mathrm{SO}_{4}$ and concentrated under reduced pressure. The residue obtained was purified by silica gel column chromatography using $1-5 \%$ ethyl acetate in petroleum ether as eluent to give pure products. The residual PEG-catalyst system was brought to room temperature and reused in next run/experiment.

\section{Supporting Information}

Supplementary data associated with this article, experimental and characterization data, can be found in the online version. 


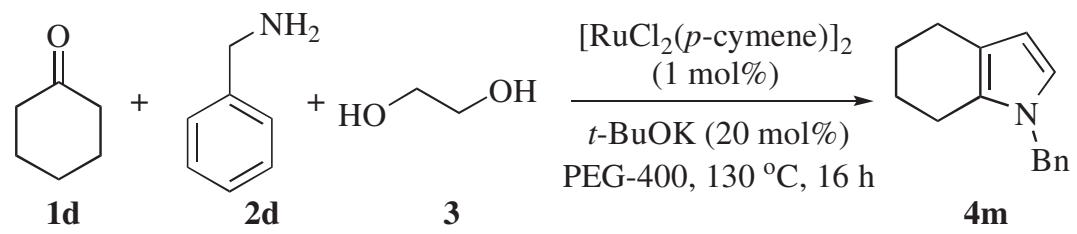

\begin{tabular}{|c|ccccc|}
\hline Run & 1st & 2nd & 3rd & 4 th & 5 th \\
\cline { 2 - 6 } Yield $(\%)^{\mathrm{a}}$ & 75 & 72 & 70 & $65(70)^{*}$ & $63(70)^{*}$ \\
\hline
\end{tabular}

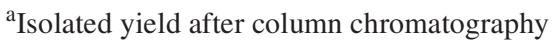

*An additional $0.2 \mathrm{~mol} \%$ 'Ru' catalyst was added to the reaction 


\begin{tabular}{|c|ccc|}
\hline Run & Ketone & Product & ${\text { Yield }(\%)^{\mathrm{a}}}^{\mathrm{a}}$ \\
\cline { 1 - 3 } 1st & $\mathbf{1 d}$ & $\mathbf{4 m}$ & 75 \\
2nd & $\mathbf{1 e}$ & $\mathbf{4 0}$ & 70 \\
3rd & $\mathbf{1 b}$ & $\mathbf{4 h}$ & $65(75)^{*}$ \\
\hline
\end{tabular}

${ }^{\text {a }}$ Isolated yield after column chromatography

*An additional $0.2 \mathrm{~mol} \%$ 'Ru' catalyst was added to the reaction 